\title{
STRUCTURAL-FUNCTIONAL DEVELOPMENT POLICIES FOR CONVERTED VILLAGES TO CITIES FOR ORDERING URBAN NETWORK. CASE OF EAST AZERBAIJAN PROVINCE/IRAN
}

\author{
B. Entezari ${ }^{1}$, M. Taleshi ${ }^{2}$, M. Musakazemi ${ }^{3}$ \\ ${ }^{1} \mathrm{Ph} . \mathrm{D}$. Student in Geography and Rural Planning, PNU, Tehran, Iran \\ ${ }^{2}$ Associated Prof. of Geography, PNU, Tehran, Iran \\ ${ }^{3}$ Associated Prof. of Geography, PNU, Tehran, Iran
}

Published online: 15 February 2017

\begin{abstract}
In IRAN Converting villages to new city centers is realized for the purpose of ordering urban networks via establishing new cities to service rural jurisdictions. But after converting to city, they have no special development plan and their authorities actually do not know about the problems to face with. This research has been done on 12 converted villages to cities in East Azerbaijan province (IRAN) by determining 100 indices in 9 main groups and using questionnaire, official data as well as geographical maps. After scoring each item and placing in a SWOT matrix it could be possible to propose special policies and plans for each settlements. The method can be easily applied in rural centers and small cities to help local authorities to make proper developmental decisions.
\end{abstract}

Keywords: Converted villages to city centers, urban network, SWOT analysis, East Azerbaijan province in IRAN.

Author Correspondence, e-mail: author@gmail.com

doi: http://dx.doi.org/10.4314/jfas.v9i1s.684 


\section{STATEMENT OF THE PROBLEM}

One of the reasons for increasing number of the cities and urban population is converting relatively large, populated villages to cities which accelerated in Iran after 1999. One of the most important problems in studying converted villages to cities, specially in macro regional plans, is that they are categorized in one group say "cities with less than 25000 population with a service role for their hinterland"; While these settlements have different features, potentials and obstacles which makes a need for establishing certain models and methods for separating them and adopting different policies and strategies for their development and role accepting in a large scale urban network of the province and even the whole country. "How planners can provide special and separated plans to each settlement or groups of settlements?" This is the main question which this research searches an answer to it. Basic assumption of the current is that a settlement will have a positive effect on urban networks if it is strong and developed enough. So he main aim of this study is finding strategies for development of small newly converted cities.

\section{LITERATURE}

There is a number of studies on small cities especially in Iran. Table 1 Shows summary of some of these studies and views:

Table 1. Some of scholars' views on converted or small scale cities

\begin{tabular}{|c|c|l|}
\hline YEAR & SCHOLAR & \multicolumn{1}{|c|}{ VIEW } \\
\hline 1982 & Deyin Zonglar & $\begin{array}{l}\text { Development of small scale cities is useful for increasing agricultural } \\
\text { products as well as exchanging goods between city and its rural } \\
\text { vicinity. }\end{array}$ \\
\hline 1982 & Ligale & $\begin{array}{l}\text { States the role of small scale cities on vicinity villages and knows } \\
\text { these cities as the engines for rural development }\end{array}$ \\
\hline 1987 & Razzaghi & $\begin{array}{l}\text { One of the main objects of the government from converting villages to } \\
\text { cities is penetrating in rural areas. }\end{array}$ \\
\hline 1991 & Poppe & $\begin{array}{l}\text { Small scale cities can provide economies of scale for introducing high } \\
\text { levels of public and economic services. }\end{array}$ \\
\hline 1992 & Gaile & $\begin{array}{l}\text { Small Scale cities can be effective tools for improving rural-urban } \\
\text { linkages. }\end{array}$ \\
\hline 1992 & $\begin{array}{l}\text { Salleh \& } \\
\text { Chogwill }\end{array}$ & $\begin{array}{l}\text { Shaping rural small scale cities is one of the methods for organizing } \\
\text { rural areas and can decrease regional differences in developing }\end{array}$ \\
\hline
\end{tabular}




\begin{tabular}{|c|c|c|}
\hline & & countries. \\
\hline 1996 & Nazariyan & $\begin{array}{l}\text { Regional studies clarify failure of this policy for diminishing regional } \\
\text { differences. }\end{array}$ \\
\hline 1994 & Pajarchaya & $\begin{array}{l}\text { In his study on Nepal, stresses on failure of small scale cities for rural } \\
\text { and regional development }\end{array}$ \\
\hline 1995 & Pederson & $\begin{array}{l}\text { Small cities can act as a middle ring between rural areas and high } \\
\text { levels of urban hierarchies. }\end{array}$ \\
\hline 1996 & Nazariyan & $\begin{array}{l}\text { Regional studies show fail of these policies as well as regional } \\
\text { differences. }\end{array}$ \\
\hline 1998 & $\begin{array}{l}\text { Hinderin \& } \\
\text { Titus }\end{array}$ & $\begin{array}{l}\text { The roles of small scale cities are very important in rural-urban } \\
\text { relations but mostly have been neglected. }\end{array}$ \\
\hline 2001 & Izadi & $\begin{array}{l}\text { These studies prepared some job opportunities and increased facilities; } \\
\text { also this policy has decreased population, capital and facilities. }\end{array}$ \\
\hline 2002 & $\begin{array}{l}\text { Eftekhari \& } \\
\quad \text { Izadi }\end{array}$ & $\begin{array}{l}\text { Small rural cities are decreasing rural migrations via creating non-farm } \\
\text { jobs and balance population, capital and facilities. }\end{array}$ \\
\hline 2004 & Zabardast & $\begin{array}{l}\text { Small scale cities are necessary for integration of rural and urban } \\
\text { economies. }\end{array}$ \\
\hline 2004 & Goli & $\begin{array}{l}\text { Converting villages to cities is done without any study and assessment } \\
\text { and many villages convert to cities with lack of prerequisites and } \\
\text { needed infrastructures. }\end{array}$ \\
\hline 2004 & $\begin{array}{c}\text { Rahnamayi \& } \\
\text { Shahoseyni }\end{array}$ & $\begin{array}{l}\text { Villages which convert to cities gain administrative and political legal } \\
\text { rights. }\end{array}$ \\
\hline 2007 & Sarabi & $\begin{array}{l}\text { Perhaps the most important role of small scale cities is transferring and } \\
\text { strengthening of development in rural effective area. }\end{array}$ \\
\hline 2007 & Rezvani, et al. & $\begin{array}{l}\text { Along with converting villages to cities, conflicts between urban and } \\
\text { rural areas are clearly decreasing. }\end{array}$ \\
\hline 2007 & $\begin{array}{l}\text { Sarabi \& } \\
\text { Eskandari }\end{array}$ & $\begin{array}{l}\text { "Rivash" (a case) has failed in stabilizing its population and spreading } \\
\text { down urban functions to rural effect area as well as offering jobs and } \\
\text { facilities to its own people. }\end{array}$ \\
\hline 2007 & $\begin{array}{l}\text { Ziyatavana \& } \\
\text { Amirentekhabi }\end{array}$ & $\begin{array}{l}\text { These cites fill the gap of urban centers in rural areas. Also they } \\
\text { reinforce commercial, administrative, educational and health services }\end{array}$ \\
\hline
\end{tabular}




\begin{tabular}{|c|c|c|}
\hline & & in their rural jurisdictions. \\
\hline 2008 & Piyon & $\begin{array}{l}\text { These cities (in China) are suitable places for developing living centers } \\
\text { and decreasing rural-urban migrations. }\end{array}$ \\
\hline 2008 & Taherkhani & $\begin{array}{l}\text { One of the negative effects of converting villages to cities has been } \\
\text { land speculation also pushing agricultural lands out of production. }\end{array}$ \\
\hline 2009 & Nasiri & $\begin{array}{l}\text { "Bumhen" (a case) has been able to stabilizing population and offering } \\
\text { jobs and facilities to its rural area. }\end{array}$ \\
\hline 2009 & $\begin{array}{l}\text { Rahmani \& } \\
\text { Parishan }\end{array}$ & $\begin{array}{l}\text { The negative aspects in "Kanisur" ( a case) include decreasing role of } \\
\text { farm activities, increasing living costs, increasing land prices as well } \\
\text { as land speculation; but positive aspects have been increasing quality } \\
\text { and quantity of educational and health services in rural effective area. }\end{array}$ \\
\hline 2009 & Noori et al. & $\begin{array}{l}\text { These cities are the beds of rural and urban development as well as } \\
\text { connecting rings of rural spaces with urban networks. }\end{array}$ \\
\hline 2010 & Rezvani et al. & $\begin{array}{l}\text { The studies on the policy's application show opposite results: while in } \\
\text { some cases the quality of life increased, in other ones decreased. }\end{array}$ \\
\hline 2011 & Barghi et al. & $\begin{array}{l}\text { Shows unsatisfying of people from increasing (house construction } \\
\text { costs and limitation of livestock activities. }\end{array}$ \\
\hline 2012 & Karimi & $\begin{array}{l}\text { His research in "Deylaman" (a case) proves failure of the converting } \\
\text { policy for regional development }\end{array}$ \\
\hline 2012 & Nikseresht & $\begin{array}{l}\text { "Sarable" (a case) has haddirect effects on development of villages and } \\
\text { increased income, public participation and expectancy of life in } \\
\text { villages. }\end{array}$ \\
\hline 2012 & Karimi et al. & $\begin{array}{l}\text { Converting "Deylaman" (a case) has had not much effect on improving } \\
\text { economic, social, cultural and environmental indices. }\end{array}$ \\
\hline 2012 & Hoseynabadi & $\begin{array}{l}\text { In developing countries, small Scale cities are a required link in rural- } \\
\text { urban linkages. }\end{array}$ \\
\hline 2013 & Izadi & $\begin{array}{l}\text { With converting "Beyza" (a case) to city, functional linkages and } \\
\text { ordering spatial relation have increased. }\end{array}$ \\
\hline 2014 & Akbarian & $\begin{array}{l}\text { Converting "Ij" (a case) to city has had an effective role on } \\
\text { development of villages but on the other hand there is no differences } \\
\text { between Ij and other villages in development indices. }\end{array}$ \\
\hline
\end{tabular}


In a sentence, these views can be divided into two groups: Theoretically speaking, these cities are successful, but practical studies show their failure and a need for planning.

\section{MATERIALS}

The case study is 12 villages in East Azerbaijan province (IRAN) which converted to cities between 2001-2011. These settlements are Tark, Kharaju, Yamchi, Aghkand, Khumarlu, Duzduzan, Siyahrud, Kharvana, Kuzekonan, Abishahmad, Bunab and Nazarkahriz as Map 1 shows. 96 questionnaires have been filled by the settlements' authorities as well as their people.

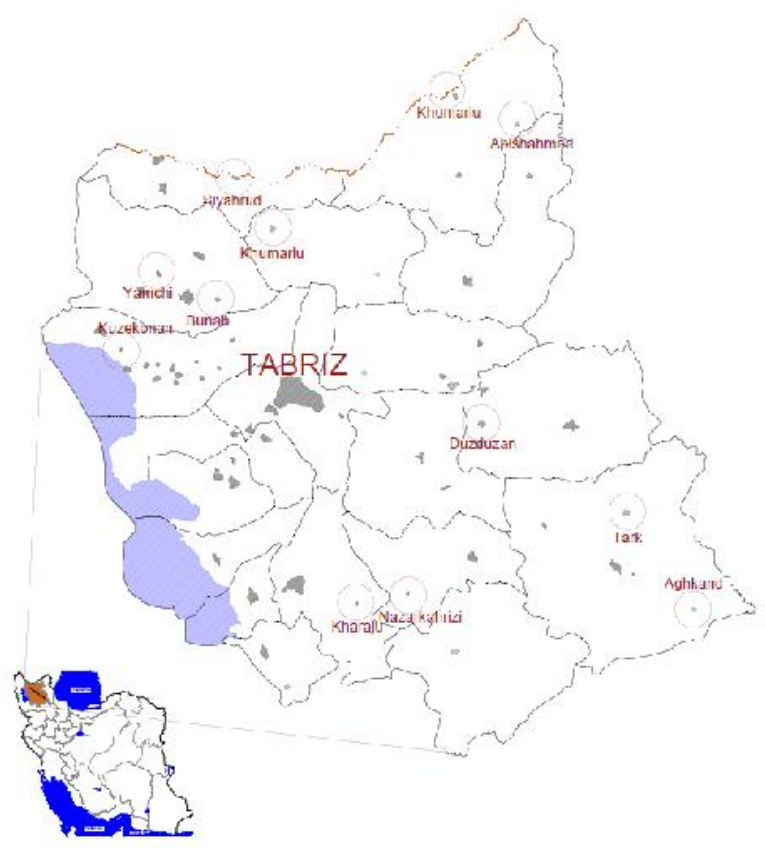

MAP 1. Location of Converted Villages in East Azerbaijan Province

\section{STUDY AREA}

"East Azerbaijan" province is located in north-west of Iran with 3.7 million people (2014). Its Capital city is "Tabriz" with more than 1.5 million inhabitants. In this province during 2001-2011 period 12 villages with a population altogether more than 35000 people have converted to cities. So using Cochran formula 96 questionnaires have been applied in this study. 


\section{RESEARRCH METHOD}

This research is a descriptive one in which after determining indices, using a questionnaire as well as statistical and geographic data and information, each index is scored then using a SWOT matrix each settlement has been analyzed for making decision and action strategies.

Using SWOT analysis is due to this fact that any settlement has after all some internal as well as external positive possibilities and negative obstacles which can be very different from other settlements and SWOT analysis is one of the simplest methods for scoring small scale settlements which can be practiced by local authorities especially in developing countries. SWOT analysis is created based on two series of positive and negative variables and in this case surveys structuralfunctional strengths and opportunities as well as weaknesses and threats of newly converted small cities.

In this research 103 indices in 9 components as below have been studied:

Component 1: (Internal - Structural): Potentials of Converted Settlements.

These are internal indices which can show a settlement's potentials for converting to a city and its ability for taking a role in urban network of the province and include: city's population number, its growth rate, tourism potentials, specialization in one or more products, number of investors, existence of suitable structures, existence of branches of different banks, number of industrial workshops, amounts of exports and so on.

Component 2: (Internal-Functional): Coordination Level in the City

These indices can also show to what extent a converted village could access to a city status from the aspects of management and human resources, Other indices show coordination levels between people and authorities, as well as people and municipality and city council numbers.

Component 3: (Internal, Structural): Infrastructures for Development

In spite of converting to cities, some of these settlements are suffering from lack of infrastructures which prevent them to take a strong role in urban network. So in this section status of gas, electricity, water and telephone has been studied.

Component 4:(Internal, Structural): Status of Different Sectors

In fact, this section is continuation of the former sector and studies other sectors like transportation, tourism, education, health and commerce which show the strengths or weaknesses of the newly converted villages in entering to urban network.

Component 5: (Internal, Functional): Organizational Obstacles 
Most of selected indices in this component are negative weaknesses of converted villages for taking a positive role in urban network and include: rural culture, public poverty, lack of attention to urban and environmental laws and regulations, lack of suitable structures for development, low levels of education among people, lack of confidence to central government or authorities, sever political tendencies, weak responses to opportunities, weak notices of news, sever religious tendencies, exceed linguistic tendencies, level of low participation of women in community affairs, more migrations especially of experts and educated people, and lack of hope for development and progress among local people.

Component 6: (External, Structural): Physical Opportunities

These opportunities can be very crucial for any converted village like number of villages and smaller cities of hinterland, distance to "Tehran", distance to "Tabriz", distance to the county's center city, distance from the main roads, locating in a strategic location, closeness to special land uses, closeness to mines, locating in a commercial free zone, distance to industrial estates, closeness to one or more large national industrial plants, closeness to national projects, locating in a touristic area.

Component 7: (External, Structural): Physical Threats

These indices opposite to above ones, are threats to a newly converted city, like closeness to preserved areas, closeness to military regions, locating in country's boarder areas, locating in a prohibited area, closeness to main faults, possibility of other natural dangers.

Component 8: (External, Functional): External Organizational Obstacles

These indices include: meritocracy in choosing local managers and authorities, coordination between the settlement's and province's offices, confidence of the capital's authorities to local people, amounts of allocated budget to the city, limitative laws and regulations of the country, centralization of "Tabriz", commercial interaction with adjacent villages and cities, relationship and official cooperation with adjacent cities.

Component 9: (External, Structural): External Opportunities from the Future Programs of the Province

There are 33 claimed projects for the near future in "East Azerbaijan" province. Each settlement has gained its scores from opportunity and chance of utilization from these programs.

RESULTS and DISSCUSSION:

Table 2 Shows scores for all settlements in the form of the sums and means for 9 components. 
Table 2. Scores of each settlement from 103 Indices

\begin{tabular}{|c|c|c|c|c|c|c|}
\hline Code & Name & $\mathbf{S}(\%)$ & $\mathbf{W}(\%)$ & $\mathbf{O}(\%)$ & $\mathbf{T}(\%)$ & Total Score \\
\hline S1 & Tark & 48.28 & 20.05 & 27.62 & 4.05 & 113.7 \\
\hline S2 & Kharaju & 50.16 & 10.06 & 21.86 & 19.79 & 128.10 \\
\hline S3 & Yamchi & 23.15 & 47.40 & 26.34 & 4.90 & 131.00 \\
\hline S4 & Aghkand & 14.41 & 49.14 & 21.95 & 15.94 & 106.30 \\
\hline S5 & Khumarlu & 21.37 & 23.64 & 44.12 & 11.75 & 146.80 \\
\hline S6 & Duzduzan & 21.08 & 28.57 & 32.41 & 19.21 & 102.80 \\
\hline S7 & Siyahrud & 21.08 & 28.57 & 32.41 & 19.21 & 102.80 \\
\hline S8 & Kharvana & 9.74 & 47.99 & 22.29 & 20.58 & 117.80 \\
\hline S9 & Kuzekunan & 49.21 & 15.84 & 17.80 & 18.73 & 109.00 \\
\hline S10 & Abishahmad & 24.96 & 33.93 & 20.56 & 22.84 & 120.90 \\
\hline S11 & Bunab & 50.94 & 24.26 & 14.54 & 12.67 & 114.80 \\
\hline S12 & Nazarkahrizi & 26.65 & 26.05 & 36.67 & 14.33 & 103.50 \\
\hline & Mean & 28.49 & 28.90 & 26.93 & 15.69 & 120.79 \\
\hline
\end{tabular}

Below status of each settlement is discussed:

\section{TARK}

"Tark" is located in "Mianeh" county, the farthest county from the province's center city (Tabriz) but on the other hand, it is the nearest one among the cases to "Tehran". Changing "TehranTabriz" path which has passed formerly from that county, caused to declining of especially commercial sector of the county and as a result of "Tark". Surveying scores of this settlement shows that in component one this settlement has relatively equal positive and negative points, but its scores in both strengths and weaknesses are more than the mean scores of 12 settlements. In components 2 and 4 this city has no negative scores and its strengths are more than weaknesses. Scores of "Tark" show that its positive points (S) in relation to other villages are higher than negative scores. In fact, considering country's underdevelopment status, relative geographical isolation in studied settlements has not caused to lack and weakness but even to farness from possible threats. So it is for "Tark" to consider its positive points. Future projects like transition 
of gas pipe and "Miyane" industrial zone can be an opportunity for "Tark". Also "Tark" has a historic mosque which can be utilized at least for internal tourism.

\section{KHARAJU}

"Kharaju" is located in "Maragha" county. "Maragha" city was once the capital city of Iran and nowadays is the second populated city of the province. This county is suffering from its geographical isolation and for this reason "Kharaju" is far from physical opportunities. In spite of this, it has good strengths. Also it can utilize future projects like "Maragha-Hashtrud" highway. So this settlement can emphasis on its internal strengths especially in component 2 and 5 and emphasizes on its agricultural products to take a role as the service city for its rural effective area. YAMCHI

Scores of "Yamchi" which is located in "Marand" county, show that it has the most negative points from its (W)s. This is the case in spite of this fact that Yamchi's economy is based on transportation sector and it is relatively a reach developing small city. This shows that "Yamchi" has to consider seriously its weaknesses. The most important opportunity for this settlement is locating on Tabriz-Europe highway. Threats in this city are in their minimum level. On the whole, its internal factors are more important than external ones.

\section{AGHKAND}

"Aghkand" is also located in "Mianeh" County. In "Aghkand" sum of weaknesses and threats are more than twice of sum of strengths and opportunities, so "Aghkand" has to work on decreasing its negative points. Also this settlement will have no use from the province's future projects. Its most important opportunity is closeness to "Tehran" which is good for private sector, but because it is the farthest city of province to Tabriz as mentioned before, officially has problems.

\section{KHUMARLU}

"Khumarlu" is located in "Kaleybar" county and is relatively far from "Tabriz". It is suffering from its rural structure. However, recently with establishing a free commercial zone, the status in "Khumarlu" is changing rapidly. Opportunities are the most important factors for this city and it can utilize from many future projects of the province and has to be ready for it.

\section{DUZDUZAN}

"Duzduzan" is located on one of the province's main roads and this is an opportunity for it. But on the whole there is no clear difference between SWOT components in this settlement. It is 
better for "Duzduzan", parallel with emphasizing on its opportunities. to work on eliminating its weaknesses and negative points.

\section{SIAHROOD}

"Siyahrood" is a boarder city and its external factors are more important than internal ones in it. Its most important opportunity comes from "Aras" free commercial zone, but on the other hand, its threats can be wide. Also it has to work on passive and active defense. "Siahrood" has also negative internal points. So parallel with emphasizing on external opportunities, it has to work on its negative points.

\section{KHARVANA}

"Kharvana" is also for from "Tabriz" and generally is located in a poor rural region. It has so many negative points and very low positive ones. Its only chance is tourism in recent years. If "Kharvana" cannot eliminate its structural obstacles, probably will not be able to utilize from its opportunities .

\section{KUZEKONAN}

It is a converted village which is very famous for its pottery works. It is located on former "Tabriz-Urumia" road which could cause for developing this area's settlements, but changing the path to new road caused to decrease of traffic.Still the positives $(\mathrm{S}+\mathrm{O}) \mathrm{s}$ of "Kuzekonan" is more than 3 times of its negatives $(\mathrm{W}+\mathrm{T})$ s. On the other side its $(\mathrm{T}) \mathrm{s}$ are more than its $(\mathrm{W}) \mathrm{s}$. So it must work on $(\mathrm{S}) \mathrm{s}$ and $(\mathrm{O}) \mathrm{s}$ to overcome to its $(\mathrm{T}) \mathrm{s}$.

\section{ABISHAHMAD}

"Abishahmad" is in Kaleybar county and has a widespread rural hinterland. Recently it is flourished due to "Motalli" hot mineral waters. But still it has negative points due to its distance from "Tabriz" and "Tehran". This city also will have opportunities from future programs of the province if it can eliminate its negative weaknesses.

\section{BUNAB}

This converted village like "Yamchi" is located in "Marand" county and their conditions are the same with this difference which it has not a very strong transportation sector. Its highest score is in its Strengths (S)s. But it has some difficulties in subject 6 which prevent its development. In external side it does not more scores and specially it will not utilize from the province's future programs. So it is better for it to consider its internal affairs that means increasing (S)s and decreasing $(\mathrm{W}) \mathrm{s}$. 


\section{NAZARKAHRIZI}

Among all 12 settlements, "Nazarkahrizi" has gained the lowest scores (98) while "Khumarlu" with 145 scores is at first place. This means "Nazarkahrizi" is a balanced settlement and is very close to mean score. Its highest score is in $(\mathrm{O})$ s from which 23 scores is utilization of the province's future projects. The best strategy for it is using $(\mathrm{S}) \mathrm{s}$ and $(\mathrm{O}) \mathrm{s}$ to overcome to $(\mathrm{W}) \mathrm{s}$.

\section{CONCLUSION}

This research has been done with this basic hypothesis which a settlement will be a good service center for its jurisdiction area and will take a suitable role in urban network if it can develop and populated enough. So 12 converted villages to cites have been analyzed for clarifying the best development strategy for each of them.

Most of tendencies are to decreasing internal weaknesses and external threats and this is true for these settlements: "Aghkand", "Siayahrood", "Kharvana" and "Abishahmad". Common characteristics of these 4 cities is farness from the province's center, closeness to the countries boarders as well as relatively underdeveloped rural community. Fortunately, in recent years with stablishing commercial free zones, as well as touristic areas most of them have are gaining more attentions.

Emphasizing internal Strengths include "Tark", "Kharaju" and "Khumarlu". All of these settlements are suffering from geographical isolation; but they have some scores from internal strengths or external opportunities. Among them, "Tark" and "Kharaju" have many internal potentials, while "Khumarlu" must thank the province's future project for having opportunities. Emphasizing internal forces is seen in 2 settlements of "Marand" county ("Yamchi" and "Bunab"). Their internal forces weight is more than their external ones.

Relying on (S)s and (O)s to overcome to $(\mathrm{W}) \mathrm{s}$ and $(\mathrm{T}) \mathrm{s}$ is seen in Duzduzan and Nazarkahrizi. Finally, in "Kuzekonan" opposite with above cases, $(\mathrm{S}) \mathrm{s}$ and $(\mathrm{O}) \mathrm{s}$ are high but $(\mathrm{T}) \mathrm{s}$ cause this city to apply its positive forces to overcome its negative ones.

The model is simply applied to other converted small scale cities as well as populated rural centers to clarifying their best development strategies. Components and indices can be modified according to local conditions. 


\section{REFERENCES}

AKBARIAN, S.(2014): The Role of Promotion of Villages to Cities in Development of Rural Areas, The Case of IJ (in Farsi); Journal of Urban and Regional Studies and Researches (Iran); 21:101-121.

BARGHI, H. et al. (2012): Satisfying Rural Local Inhabitants from Converting Rural Points to Cities (in Farsi); Journal of Geography, 31:215-233.

BUTA, Romică (2007): The SWOT Analysis in the Geographical Research, with Applicability in the study of the Human Settlements from Moldova Valley (Baia-Draguseni Sector); Environment and Sustainable Development, 1: 239-248.

Deyin, Yu and Zongfen, Sun. (1982): “The Strategic Objective of Urban Development in China: Taking Vigorous Action to Develop Small Cities." In Small Cities and National Development, edited by Om Prakash Mathur, 23-33. Nagoya, Japan: United Nations Centre for Regional Development

EFTEKHARI, A. and IZADI, H. (2002): Hierarchy Location of Rural Settlements (in Farsi); Journal of Geographical Researches (Iran); 39.

GAILE, G. (1988): Choosing Locations for Small Town Development to Enable Market and Development Expansion. Economic Geography 64, 3, 242-253.

GOLI, Ali (2004): Analyzing Process of Transition from Village to City and Designing a Model for Detecting Transitional Villages in Iran (in Farsi); Tarbiyat Modarres University.

HINDERIN K, J. and TITUS, M. (2002): Small Towns and Reginald Development: Major Findings', Urban Studies, Vol 39, No.30.

IZADI, H. (2013): Converting Village to City and its Role in Rural Development, The Case of Fars County (in Farsi); “Tarbiat Modarres” Publications; Tehran, Iran.

KARIMI, B. et al. (2012 ): Assessment of Effects of Converting Villages to Cities in Development of Mountainous Regions, The Case of "Deylaman" (in Farsi); Journal of Rural Housing and Environment (Iran); 145:95-110.

LEGALE, A. A. (1982): The Role of Small and Intermediate Cities in National Development in Africa, UNCRD, Nagoya, Japan.

NASIRI, E. (2010): The Role of Small Cities in Organizing Spatial Order, the Case of "Bumhen" (in Farsi); Journal of Geography and Regional Planning (Iran), 2010:27-42. 
NAZARIAN, M. (1996): Position of Small Cities in Spatial Organization and National Development (in Farsi); Geographic Research, 49, 52-64.

NIKSERESHT, M. et al. (2012): Analyzing Function of Small Cities in Developing Peripheral Villages, the Case of "Sarbleh" (in Farsi); Journal of Regional Planning; 7:53-64.

NOORI, H. et al. (2010): The Role of Small Cities in Balancing Rural Settlement System of Yazd Province (in Farsi); Journal of Geography and Development (Iran); 13:61-77.

PEDERSON, J.K. et al. (2014): Mapping Smart Cities in the EU.; European Parliament.

POPPE, M. (1991): Structure Planning for Medium-Sized Towns in Egypt, Problem Oriented Approach; Third World Planning Review, 13(4):335-355.

RAHMANI, A. and PARISHAN, M. (2010): Structural-Functional Changes after Converting Rural Points to Cities, the Case of "Kanisur" (in Farsi); Journal of Applied Researches of Geographic Sciences; 12:101-128.

REZVANI, M. et al. (2008): The Role and Function of Small Cities in Rural Development Using Network Analyzing Method, the Case of "Runiz"; (in Farsi); Journal of Geographical Researches (Iran); 55:45-58.

REZVANI, M. et al. (2010): Promotion of Villages to Cities and their Role in Improving Quality of Life of Local Inhabitants, the Case of "Firuzabad" and "Saheb" Cities (in Farsi); Journal of Rural Researches (Iran); 1:33-65.

RONDINELLI, D. A. (1987): Cities as Agricultural Markets. Geographical Review 77, 4, 408420.

SALLEH, Gh. and CHOGUILL, Ch. (1991): Impact of New Towns in Rural Regions: Case Study of Central Terengganu Region, Malaysia; Paperback University of Sheffield Dept. Of Town \& Regional Planning; England.

SARAYI, M. and ESKANDARI, M. (2008): Converting Large Villages to Small Cities and its Role in Regional Balancing, the Case "Rivash"; (in Farsi); Journal of Geography and Development (Iran); 10:165-182.

TAHERKHANI, (2000): Converting Large Villages to Cities, A view to a Policy (in Farsi), Journal of Municipalities (Iran), 5.

TALESHI, M. and MOHAMMADI, M. (2012): The Role of Small Towns Instability of Rural Development, The Case of small cities of "Babol" County in North Iran; 2J. Basic Appl. Sci. Res. 2(7):6795-6800. 
ZANGANEH, S. (2014): The Process of Converting Rural Points to Cities in National Scale and Emerging "Raw Cities" (in Farsi); Journal of Rural Researches; 3:535-557.

ZIYATAVANA, M. and AMIRENTEKHABI, Sh. (2008): Converting Villages to Cities and its Results in "Talesh" County (in Farsi); Journal of Geography and Development (Iran); 10:107128.

\section{How to cite this article:}

Entezari B, Taleshi M, Musakazemi M. Structural-functional development policies for converted villages to cities for ordering urban network. Case of east azerbaijan province/iran. J. Fundam. Appl. Sci., 2016, 9(1S), 140-153. 